$\begin{array}{ll}\text { Volume } & : 7 \\ \text { Nomor } & : 3 \\ \text { Bulan } & : \text { Agustus } \\ \text { Tahun } & : 2021\end{array}$

\title{
Analisis Kebutuhan Pengembangan Permainan Kartu Domino sebagai Media Pembelajaran Operasi Hitung Perkalian Siswa Kelas IV SD
}

\author{
Auliya Robiah Adawiyah \\ Kowiyah \\ Universitas Muhammadiyah Prof. Dr. Hamka \\ Pos-el: auliyarobiah@gmail.com,kowiyah_agil@uhamka.ac.id
}

DOI: $10.32884 /$ ideas.v7i3.435

\begin{abstract}
Abstrak
Keterampilan operasi perkalian sangat penting dalam pendidikankarena operasi perkalian merupakan inti dasar mata pelajaran matematika hingga tingkat tinggi. Fungsi media pada pembelajaran yakni menyampaikan informasi selama pembelajaransehingga menginspirasi siswa untuk belajar. Terdapat banyak variasi media pembelajaran operasi perkalian, di antaranya media permainan kartu. Permainan kartu ini disebut domino. Penelitian ini menggunakan survei kuesioner dengan teknik pengumpulan data melalui kuesioner dan angket dikategorikan sesuai dengan kebutuhan target yang diujicobakan kepada siswa kelas IV SD dengan latar sekolah yang berbeda. Tujuan pada penelitian ini yakni ingin mengetahui kebutuhan dalam pengembangan permainan kartu domino, media pembelajaran yang digunakan oleh guru pada pembelajaran operasi perkalian, dan tingkat ketahuan para siswa terkait dengan media kartu domino tersebut. Adapun hasil penelitian menunjukkan tingkat implementasi media pada pembelajaran mendapatkan skor sebesar $78,1 \%$ dan respons positif terhadap permainan kartu sebesar $78,1 \%$.
\end{abstract}

Kata Kunci

pembelajaran matematika, keterampilan operasi hitung perkalian, media pembelajaran operasi hitung perkalian, dan permainan kartu domino

\begin{abstract}
Multiplication operation skills are very important in education, because multiplication operations are the basic core of mathematics subjects to a high level. The function of the media in the learning is to convey information during learning, so that it inspires students to learn. There are many variations of multiplication operation learning media, including card game media. This study used a questionnaire survey with data collection techniques through questionnaires and questionnaires categorized according to the needs of the target were tested on fourth grade elementary school students with different school backgrounds. The purpose of this study is to find out the needs in the development of domino card games, the learning media used by teachers in learning multiplication operations, and the level of discovery by students related to the domino card media. The results of the study show that the level of media implementation in learning gets a score of $78,1 \%$ and a positive response to card games is $78,1 \%$.
\end{abstract}

Keywords

learning mathematics, multiplicationcounting operation skills, learning media for multiplication counting operations, and domino card games

\section{Pendahuluan}

Matematika merupakan ilmu bersifat universal yang harus diajarkan kepada siswa Sekolah Dasar (SD) atau Madrasah Ibtidaiyah (MI) (Crismono, 2017). Tujuan dari pengimplementasian pembelajaran matematika adalah masyarakat mengharapkan para siswa dapat mengapresiasi kegunaan matematika dalam dunia pendidikan, seperti tertarik untuk belajar matematika dan yakin dalam memecahkan masalah.

Keterampilan operasi perkalian merupakan dasar dari pelajaran matematika karena dapat dikatakan keterampilan yang diperlukan untuk mempelajari materi selanjutnya. Namun, kenyataannya dapat dilihat dari siswa kelas atas yang belum sepenuhnya menguasai materi perkalian. Banyak dari siswa tingkat atas yang mengalami kesulitan dalam mempelajari matematika tingkat yang lebih tinggi dikarenakan pada pembelajaran

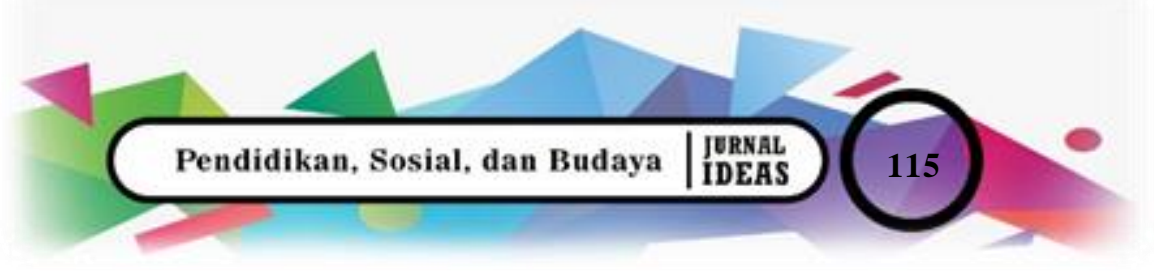


matematika banyak memuat konsep abstrak, serta perumusan yang rumit dalam hitungannya sehingga membutuhkan ketelitian dalam mengerjakannya (Kowiyah, 2016).

Dalam proses perkembangan kognitif siswa sekolah dasar, mereka masih terikat oleh objek tertentu yang ditangkap oleh pancaindra. Oleh karena itu, guru perlu meninjau cara menentukan media pembelajaran yang efektif demi tercapainya suatu tujuan dari pembelajaran.

Berdasarkan hasil data survei yang peneliti sebar melalui kuesioner didapatkan hasil sebanyak 100 siswa dengan 13 latar sekolah yang berbeda, hasil analisis kebutuhan penggunan media disebabkan oleh $29,2 \%$ siswa kelas IV SD belum menggunakan media kartu dikarenakan sebagian besar guru belum berinovasi pada pembelajaran matematika. Selain itu, disebabkan karena pada pembelajaran operasi perkalian para siswa hanya fokus dengan penjelasan dari guru tanpa melalui media pembelajaran. Dengan demikian, peneliti merekomendasikan pengembangan permainan kartu untuk memecahkan permasalahan tersebut.

Pembelajaran di sekolah sudah mulai beradaptasi dengan perkembangan teknologi. Dengan demikian, akan terjadinya suatu perubahan (Rijal, 2020). Saat belajar matematika di sekolah dasar guru harus mampu mengajarkan matematika semaksimal mungkin agar proses pembelajaran menjadi bermakna. Menurut Hamzah \& Muhlisrarini (2014) esensi matematika adalah ilmu yang membahas masalah numerik yang berkaitan dengan kuantitas. Sementara itu, konsep pembelajaran matematika bersifat abstrak, untuk memahaminya diperlukan konsentrasi dan keseriusan yang tinggi (Sitti Hartinah \& Setiawan, 2013).

Menurut pendapat ahli tersebut dapat disimpulkan bahwa dalam pembelajaran matematika siswa harus mampu mengeksplor dirinya terlebih dahulu dalam memahami materi matematika tersebut, seperti bagaimana cara siswa dalam menyelesaikan soal, serta siswa harus mampu menemukan rumus yang paling mudah untuk diaplikasikan dalam materi tersebut.

Media diperlukan sebagai alat bantu guru dalam penjelasan pelajaran di dalam kelas. Penggunaan media dalam pembelajaran sangat diperlukan sehingga dapat digunakan sebagai contact person pembelajaran agar tercapai tujuan pembelajaran secara efektif dalam pemanfaatan waktu. Buchori \& Setyawati (2015) mendefinisikan media sebagai faktor penentu dalam pembelajaran, sedangkan menurut Muhsetyo (dalam Hakim \& Windayana, 2016) menyatakan bahwa media merupakan alat bantu belajar yang sengaja direncanakan guru untuk mempersiapkan penjelasan materi pelajaran dan memungkinkan siswa berpartisipasi secara langsung dalam pembelajaran matematika.

Media yang menarik dapat merangsang motivasi belajar siswa. Secara umum, media memiliki fungsi. Menurut Sudjana dan Rivai (dalam Ihsana El Khuluqo, 2017) media pembelajaran memiliki lima fungsi utama dalam proses pembelajaran, di antaranya sebagai berikut.

1. Sebagai alat untuk menciptakan suasana pengajaran yang berhasil.

2. Media pengajaran adalah suatu bagian yang tidak terpisahkan.

3. Menggunakan media pengajaran harus tahu tujuannya.

4. Media dapat mempersingkat pembelajaran dan mendukung siswa menguasai materi pembelajaran.

5. Untuk meningkatkan kualitas belajar dan mengajar.

Media berkedudukan paling utama dalam mengembangkan keunggulan dunia pendidikan, termasuk pendidikan matematika. Beberapa media yang sering dimanfaatkan pada pembelajaran antara lain media cetak, elektronik, dan modul (Yaumi, 2017). Tujuan menggunakan media untuk memahami simbol matematika melalui pengenalan khusus yang sesuai dengan tingkat berpikir siswa. Menurut Muhsetyo (2011) media pembelajaran matematika adalah suatu perangkat pembelajaran matematika yang dirancang untuk membantu siswa dalam memahami buku teks mata pelajaran matematika.

Permainan kartu pada pelajaran matematika di Indonesia beraneka ragam dengan penyebutan, di antaranya domino matematika (domat) dan domino numbers. Pada permainan domat terletak dua persegi bilangan, sedangkan pada domino numbers terletak isian kartu berupa soal dan jawaban dan termasuk media yang sangat mudah diperoleh karena bahan-bahannya mudah ditemukan (Isma \& Hidayah, 2015).

Pada penelitian ini, peneliti mendapat bantuan dari hasil penelitian relevan. Peneliti menemukan beberapa penelitian lain yang memiliki persamaan dan perbedaan pada penelitian ini. Penelitian relevan pertama berasal dari FITA (2021) masalah yang melatarbelakangi pada penelitian ini karena belum adanya inovasi media berupa aplikasi dalam kegiatan belajar mengajar di kelas. Pada penelitian relevan terakhir berasal dari Rulandari (2018) masalah yang melatarbelakangi pada penelitian ini karena guru cenderung menerapkan pembelajaran konvensional yang sangat monoton dan guru belum menggunakan media yang menarik dalam menjelaskan materi operasi 


$\begin{array}{ll}\text { Volume } & : 7 \\ \text { Nomor } & : 3 \\ \text { Bulan } & : \text { Agustus } \\ \text { Tahun } & : 2021\end{array}$

perkalian. Mengenai perbedaan darikedua penelitian tersebut adalah yang pertama berbeda dari jenis media, kedua berbeda dalam intansi sekolah dan pengambilan objek kelas, dan ketiga berbeda dalam tujuan penelitian. Adapun kebaharuan pada penelitian ini adalah ingin mengetahui berbagai analisis faktor dalam mengembangkan kartu domino sebagai media pembelajaran operasi perkalian siswa kelas IV SD.

Tujuan dari penelitian ini yakni ingin mengetahui kebutuhan dalam pengembangan permainan kartu domino, media pembelajaran yang digunakan oleh guru pada pembelajaran operasi perkalian, dan tingkat ketahuan para siswa terkait dengan media kartu domino tersebut.

\section{Metode}

Metode penelitian yang digunakan adalah: Penelitian kualitatif dengan metode survey. Dalam pengumpulan data berasal dari pendapat para subjek yang dituju. Teknik untuk mengumpulkan data yang digunakan yakni wawancara dengan memberikan kuesioner melalui google formulir. Kuesioner ditujukkan kepada para siswa kelas IV dengan minimal berjumlah 100 siswa. Untuk sekolah yang dituju dalam target penelitian ini yakni minimal dari lima sekolah yang berbeda.

Adapun responden pertama berasal dari SDN Jatibening dengan jumlah 7 siswa, responden kedua berasal dari MI Al Islamiyah dengan jumlah 1 siswa, responden ketiga berasal dari MI Igrobatussadah dengan jumlah 1 siswa, responden keempat berasal dari SDN Karang Tengah dengan jumlah 26 siswa, responden kelima berasal dari SDN Jelambar Baru 05 dengan jumlah 51 siswa, responden keenam berasal dari SDN Jelambar Baru 03 dengan jumlah 3 siswa, responden ketujuh berasal dari SDN Wijaya Kusuma dengan jumlah 1 siswa, responden kedelapan berasal dari SDN Duri Kosambi 06 dengan jumlah 3 siswa, responden kesembilan berasal dari SDN Srengseng 06 dengan jumlah 1 siswa, responden kesepuluh berasal dari SDN Meruya Utara dengan jumlah 2 siswa, responden kesebelas berasal dari SDN Pulo Gadung dengan jumlah 2 siswa, responden kesebelas berasal dari SDM Muhammadiyah 11 dengan jumlah 1 siswa, dan responden terakhir berasal dari SDN Semanan 09 dengan jumlah 1 siswa.

Tujuan dari penelitian ini yakni ingin mengetahui kebutuhan dalam pengembangan permainan kartu domino, media pembelajaran yang digunakan oleh guru pada pembelajaran operasi perkalian, bagaimana proses para siswa dalam menghafalkan operasi hitung perkalian, dan tingkat ketahuan para siswa terkait dengan media kartu domino tersebut.

Penelitian ini dilaksanakan melalui penyebaran kuesioner berupa pertanyaan wawancara dimulai dari tanggal 23 Mei 2021. Cara penyebaran kuesioner tersebut dilakukan secara online. Penyebaran kuesioner melalui google formulir diberikan kepada pendidik melalui WhatsApp. Untuk penyebaran kepada peserta didik diberikan melalui WhatsApp group pendidik tersebut. Kuesioner yang diberikan memiliki tujuh pertanyaan untuk peserta didik. Pertanyaan-pertanyaan tersebut berkaitan dengan kebutuhan pengembangan permainan kartu domino, dan tingkat ketahuan peserta didik terkait media kartu domino.

Pertanyaan-pertanyaan yang diberikan kepada peserta didik dapat dijabarkan melalui tabel berikut ini.

Tabel 1

List Pertanyaan Wawancara Siswa Kelas IV SD

\begin{tabular}{ll}
\hline No & List Pertanyaan \\
\hline 1 & Apakah bapak/ibu guru menggunakan media pada pelajaran matematika? \\
\hline 2 & Jika ya, sebutkan salah satu media y ang digunakan guru saat pembelajaran matematika? \\
\hline 3 & Dalam pembelajaran matematika operasi hitung perkalian, apakah guru menggunakan media pembelajaran? \\
\hline 4 & Apakah ibu/bapak guru pernah menggunakan media kartu saat mengajar operasi hitung perkalian? \\
\hline 6 & Menurutmu, media y ang digunakan guru memudahkan kamu dalam memahami materi pelajaran? \\
\hline 7 & Terdapatkah dampak positif y ang kamu rasakan setelah belajar menggunakan media pembelajaran? \\
\hline
\end{tabular}

\section{Hasil dan Pembahasan}

Hasil

Penyebaran kuesioner dibagikan dari tanggal 23 Mei 2021 hingga tanggal 16 Juni 2021 mendapatkan perespon yang sudah cukup mencapai target yang dituju. Untuk jumlah perespon dari jumlah sekolah yang mengisi kuesioner yakni mendapatkan 13 sekolah dengan jumlah 100 siswa. Untuk lebih jelasnya, jumlah perespon berdasarkan sekolahnya dapat dilihat melalui gambar 1 berikut. 


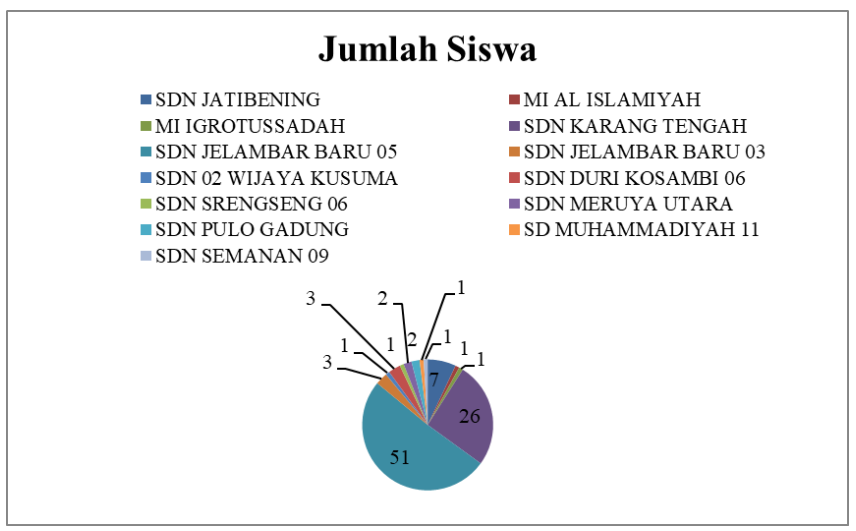

Gambar 1 Nama Sekolah dan Jumlah Responden

Dari data di atas dapat diketahui bahwa terdapat 100 siswa dari 13 latar sekolah yang berbeda. Hasil yang diperoleh dalam kuesioner tersebut, dapat dijelaskan melalui setiap pertanyaan sesuai pada nomornya berikut ini.

\section{Pembahasan}

Pada pertanyaan pertama diawali dengan membahas pemanfaatan media pada pembelajaran matematika. Dari pernyataan tersebut didapatkan hasil $78,1 \%$ bagi guru yang sudah memanfaatkan media pada pelajaran matematika, dan $21,9 \%$ bagi guru yang tidak memanfaatkan media pada pelajaran matematika sehingga dapat disimpulkan bahwa masih sebagian dari pendidik yang belum memanfaatkan media saat pelajaran matematika. Hal ini sesuai dengan penelitian dari Moto (2019) bahwa media mampu memberikan dampak signifikan pada proses dan hasil belajar siswa.

Pada pertanyaan kedua membahas tentang variasi media pembelajaran yang kadang kala digunakan oleh bapak/ibu guru saat pembelajaran matematika. Didapatkan hasil media pembelajaran berupa buku tematik sebesar 28\%, video YouTube sebesar 36\%, tabel perkalian sebesar 8\%, tidak menggunakan media pembelajaran sebesar $24 \%$, dan sempoa sebesar $4 \%$ sehingga dapat dikatakan bahwasannya variasi media pembelajaran yang kadang kala digunakan saat pembelajaran matematika ialah media video YouTube. Hal ini sesuai dengan penelitian dari Mulyawati dkk., (2020) hal keperluan penggunaan video pembelajaran sebagai penunjang pemahaman peserta didik karena media audio dalam pengajaran merupakan jenis bahan yang mengandung informasi berupa pendengaransehingga dapat merangsang pikiran, perasaan, pandangan, dan ambisi siswa (Netriwati \& Lena, 2018).

Pada pertanyaan ketiga, membahas mengenai pemakaian media pada pelajaran matematika operasi hitung perkalian. Dari pernyataan tersebut didapatkan hasil sebesar $74 \%$ guru menggunakan media pembelajaran dan $26 \%$ guru belum menggunakan media saat pembelajaran matematika operasi hitung perkalian berlangsung. Hal tersebut sesuai dengan penelitian dari (Sarumaha, 2020) menyatakan urgensi dari media pembelajaran adalah suatu alat perantara yang melibatkan siswa dalam upaya memperoleh

Pada pertanyaan keempat, membahas tentang pernyataan penggunaan media kartu saat mengajar operasi hitung perkalian. Dari pernyataan tersebut didapatkan hasil sebesar $29,2 \%$ guru pernah menggunakan media kartu saat mengajar operasi perkalian, tetapi sebagian besar guru belum menggunakan media kartu tersebut sebesar 70,8\% sehingga dapat disimpulkan bahwasannya tingkatan persentase guru yang tidak menggunakan media kartu saat mengajar operasi hitung perkalian lebih besar dibandingkan dengan guru yang menggunakan media kartu pada saat pembelajaran matematika operasi hitung perkalian. Hal ini sesuai dengan penelitian dari Suwarto (2017) menyatakan bahwa strategi belajar menggunakan benda konkret akan membantu siswa dalam memahami operasi bilangan.

Pada pertanyaan kelima, membahas tentang pernyataan urgensi dari media pembelajaran dapat mempermudah siswa dalam mencerna subjek pelajaran. Dari pernyataan tersebut didapatkan hasil sebesar 91,7\% siswa mengatakan media yang digunakan guru dapat mempermudah para siswa dalam mencerna subjek pelajaran. Dengan demikian, hal tersebut sesuai dengan penelitian dari Pangestu (2017) menyatakan urgensi media dalam pembelajaran merupakan bagian yang penting karena media pembelajaran menyediakan berbagai metode beserta jenis-jenis dari media tersebut. 


$\begin{array}{ll}\text { Volume } & : 7 \\ \text { Nomor } & : 3 \\ \text { Bulan } & : \text { Agustus } \\ \text { Tahun } & : 2021\end{array}$

Pada pertanyaan keenam membahas tentang pernyataan apakah terdapat dampak positif yang siswa rasakan setelah belajar menggunakan media pembelajaran. Dari pernyataan tersebut didapatkan hasil sebesar $89,6 \%$ terdapat dampak positif yang para siswa rasakan setelah belajar menggunakan med ia pembelajaran. Hal ini berbanding dengan tinjauan pembahasan dari Aprinawati (2017) bahwa terdapat dampak positif dari media pembelajaran, yaitu dapat mengembangkan hasil belajar siswa.

Pada pernyataan ketujuh membahas tentang pernyataan apakah siswa senang belajar sambil bermain dalam menghafal operasi hitung perkalian beserta dengan alasannya. Dari pernyataan tersebut didapatkan hasil sebesar $78,1 \%$ para siswa senang belajar sambil bermain dengan alasan karena belajar sambil bermain dalam menghafal operasi hitung perkalian dapat menyenangkan, lebih mudah diingat, dan tidak membosankan. Adapun jumlah persentase dengan alasan lebih mudah diingat sebesar 44\%karena alasan menyenangkan sebesar 28\%, dan karena alasan tidak membosankan sebesar 9\%. Hal tersebut sesuai dengan penelitian dari Yusnita dkk., (2016) menyatakan bahwa permainan dalam pembelajaran merupakan aktifitas dalam mencapai perkembangan yang utuh, baik fisik, intelektual, sosial, maupun emosional.

\section{Simpulan}

Penelitian ini berkaitan dengan media pembelajaran pada pelajaran matematika operasi perkalian, yakni jenisjenis media yang sering digunakan oleh pendidik pada pembelajaran matematika operasi perkalian adalah buku tematik, video pembelajaran, dan tabel perkalian. Dari pandangan peserta didik, media yang disajikan oleh pendidik sudah dapat dipahami oleh siswa dikarenakan adanya penambahan penjelasan dari pendidik sehingga dapat disimpulkan bahwa pendidik lebih sering menggunakan video pembelajaran sebagai sarana media pembelajaran matematika operasi hitung perkalian. Adapun tanggapan positif dari sebagian besar para siswa tentang adanya pengembangan media kartu domino.

Diharapkan dengan adanya analisis kebutuhan penerapan permainan kartu domino mampu memberikan alasan secara umum yang dirasakan oleh peserta didik dan semoga ke depannya dapat memudahkan para siswa dalam mengingat operasi hitung perkalian, dan membuat para siswa semangat dalam menghafalkan operasi hitung perkalian.

\section{Daftar Rujukan}

Aprinawati, I. (2017). Penggunaan Media Kartu Domino Bilangan untuk Meningkatkan Hasil Belajar Matematika Siswa Kelas V SD. Jurnal Pelangi, 9(2).

Buchori, A., \& Setyawati, R. D. (2015). Development learning model of charactereducation through e-comic in elementary school. International Journal of Education and Research, 3(9), 369-386.

Crismono, P. C. (2017). Pengaruh outdoor learning terhadap kemampuan berpikir kritis matematis siswa. Jurnal Pendidikan Matematika Dan Sains, 5(2), 106-113.

FITA, W. T. (2021). PENGEMBANGAN APLIKASI PERMAINAN MULTYPLY CARDS SEBAGAI MEDIA PEMBELAJARAN OPERASI HITUNG PERKALIAN PADA KELAS 3 SD/MI. UIN RADEN INTAN LAMPUNG.

Hakim, A. R., \& Windayana, H. (2016). Pengaruh Penggunaan Multimedia Interaktif Dalam Pembelajaran Matematika Untuk Meningkatkan Hasil Belajar Siswa SD. EduHumaniora | Jurnal Pendidikan Dasar Kampus Cibiru. https://doi.org/10.17509/eh.v4i2.2827

Hamzah, A., \& Muhlisrarini, 2014. (2014). Perencanaan dan Strategi Pembelajaran Matematika (2nd ed.).

Ihsana El Khuluqo. (2017). Belajar dan Pembelajaran (Konsep Dasar, Metode Dan Aplikasi Nilai-Nilai Spritualitas Dalam Proses Pembelajaran (1st ed.).

Isma, Y. E. N., \& Hiday ah, R. (2015). Development of Domino Chemistry Game Card Media to Practice Analy tical Thinking Skills of Students in Chemical Bonding Topic of Class X Semester 1. Journal of Chemical Education, 386-392.

Kowiy ah. (2016). Peningkatan Kemampuan Berpikir Kritis dalam Pemecahan Masalah Matematis Menggunakan Pendekatan Open Ended. Jurnal Inovasi Pendidikan Dasar, 5(1), 67-74. http://jipd.uhamka.ac.id/index.php/jipd/article/view/48

Moto, M. M. (2019). Pengaruh Penggunaan Media Pembelajaran dalam Dunia Pendidikan. Indonesian Journal of Primary Education. https://doi.org/10.17509/ijpe.v3i1.16060

Muhsetyo, G. (2011). Pembelajaran Matematika SD. Universitas Terbuka.

Mulyawati, I., Supriansyah, S., \& Kowiyah, K. (2020). Implementasi Penerapan Media Pembelajaran di Sekolah Dasar Muhammadiy ah Jakarta Timur. SEMINAR NASIONAL PGSD UHAMKA 2020, 57-64.

Netriwati, M. S. L., \& Lena, M. S. (2018). Media Pembelajaran Matematika. Bandar Lampung: Permata Net.

Pangestu, B. A. (2017). Pemanfaatan media pembelajaran dalam pendidikan. Seminar Nasional Pendidikan.

Rijal, A. S. (2020). Pengembangan Media Pembelajaran Berbasis Web Untuk Meningkatkan Kreativitas Guru. 2507(February), 1-9.

Rulandari, R. A. (2018). Pengaruh Penggunaan Media Permainan Multiplication Card Terhadap Hasil Belajar Kognitif Matematika Siswa Kelas II di SDN Anggaswangi 2 Sidoarjo. Universitas Muhammadiy ah Sidoarjo.

Sarumaha, R. (2020). UPAYA MENGATASI KESULITAN SISWA DALAM OPERASI PERKALIAN DENGAN

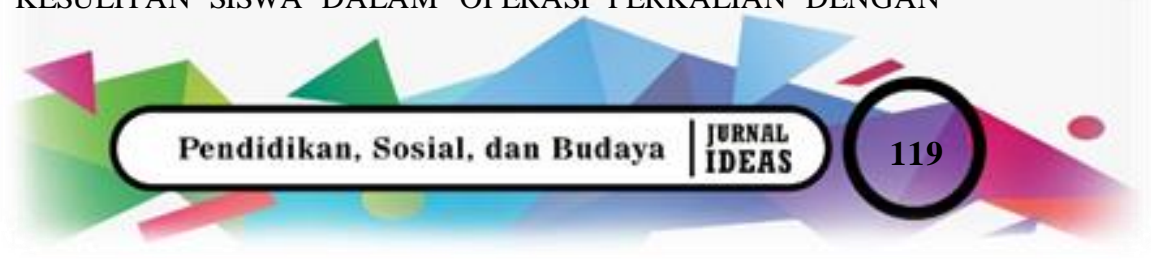


Volume $: 7$

METODE LATIS DI KELAS VII SMP NEGERI 1 LUAHAGUNDRE MANIAMOLO TAHUN PEMBELAJARAN 2019/2020. JURNAL PEMBELAJARAN DAN MATEMATIKA SIGMA (JPMS). https://doi.org/10.36987/jpms.v6i1.1608 Sitti Hartinah, D. S., \& Setiawan, T. (2013). Sikap Guru Taman Kanak-Kanak Terhadap Pembelajaran Matematika. Jurnal Ilmu Pendidikan, 19(1).

Suwarto, S. (2017). STRATEGI PEMBELAJARAN OPERASI BILANGAN DENGAN BENDA KONKRET. UNION: Jurnal Ilmiah Pendidikan Matematika. https://doi.org/10.30738/.v5i3.1437

Yaumi, M. (2017). Ragam Media Pembelajaran. Seminar Nasional Dan Workshop Pemanfaatan Media Pembelajaran Dan Pengembangan Evaluasi Sistem Pembelajaran Berorientasi Multiple Intelligences.

Yusnita, A., Rangan, A. Y., \& Setiawan, F. (2016). MEMBANGUN GAME FUN ANIM AL PUZZLE MENGGUNAKAN ALGORITM A SHUFFLE RANDOM. Sebatik. https://doi.org/10.46984/sebatik.v15i1.68 